\title{
PERSYARATAN KANDUNGAN LOKAL (LOCAL CONTENT REQUIREMENTS) DI INDONESIA DAN KAITANNYA DENGAN PERJANJIAN INTERNASIONAL DI BIDANG INVESTASI
}

\author{
Esty Hayu Dewanti \\ Pengamat Hukum, esty.hayu@yahoo.com
}

\begin{abstract}
As a popular policy in developing countries, local content requirement requires the multinational corporation to use certain amount of components which are produced in the host country in order to give protection to the local industries (national protection). The local content policy has given benefits for developing countries such as an expansion of employment and transfer of technology to the society. Due to the reasons, Indonesia also implemented the local content policy in various sector for example automotive, electronic, oil and gas, etc and it has been legalize in the Indonesian technical regulation. On the other hand, the local content policy violated the national treatment principle which is stated in Article III, 4 GATT and paragraph IA Annex TRIMs. The national treatment principle defined as the principle which gives the foreign investors/investment no less favorable treatment than the local investors/investment. It is realized that the local content policy has raised the discrimination of some imported product and it should be abolished within certain period as stated in TRIMs.
\end{abstract}

Keywords: local content requirements, national treatment, national protection

\begin{abstract}
Abstrak
Kebijakan local content requirements merupakan kebijakan popular di Negara berkembang yang mensyaratkan perusahaan multinasional untuk menggunakan prosentase tertentu dari bahan dan komponen-komponen tertentu yang diproduksi dalam negeri sebagai suatu bentuk perlindungan trehadap industri domestik (national protection). Selain itu kebijakan local content requirements dianggap menguntungkan karena memberikan keuntungan berupa perluasan lapangan kerja dan peningkatan transfer teknologi bagi masyarakat. Oleh karena itu, Indonesia menerapkan kebijakan ini dalam berbagai bidang usaha seperti otomotif, elektronik, migas dan lainnya yang dituangkan dalam regulasi teknisnya. Di sisi lain kebijakan ini bertentangan dengan prinsip national treatment yang terdapat dalam Article III,4 GATT maupun Paragraph I A Annex TRIMs. Prinsip national treatment merupakan prinsip yang memberikan perlakuan sama baik terhadap investor asing/local maupun terhadap investasi asing/lokal sehingga kebijakan local content dinilai sebagai kebijakan diskriminatif terhadap barang impor dan harus dihapuskan dalam jangka waktu tertentu berdasarkan kesepakatan dalam TRIMs.
\end{abstract}

Kata Kunci: Local Content Requirements, National Treatment, National Protection. 


\section{Pendahuluan}

Di dalam suatu laporannya yang diterbitkan pada tahun 1996, World Trade Organization (selanjutnya disebut WTO) menunjukkan bahwa telah terjadi suatu perkembangan yang cukup mendasar di bidang penanaman modal, khususnya sejak tahun 1980-an. ${ }^{1}$ Perkembangan tersebut merupakan suatu keharusan atau keniscayaan, karena investasi adalah merupakan salah satu motor penggerak roda ekonomi agar suatu negara dapat mendorong perkembangan ekonominya selaras dengan tuntutan perkembangan masyarakatnya. ${ }^{2}$

Perkembangan di bidang penanaman modal di atas ditandai dengan meningkatnya kesadaran negara bahwa penanaman modal asing berperan penting baik di negara maju maupun negara sedang berkembang. ${ }^{3}$ Peranan penting tersebut dikarenakan negara maju dengan kemajuan teknologi yang pesat tetapi memiliki pasar yang menjenuhkan dan negara berkembang (developing countries) dengan teknologi yang kurang namun merupakan pasar potensial yang belum dieksplorasi. ${ }^{4}$ Ketika perusahaan dari negara maju lebih memilih untuk mengekspor produk-produknya ke

\footnotetext{
${ }^{1}$ Huala Adolf, "Perjanjian Penanaman Modal Dalam Hukum Perdagangan Internasional (WTO)", Bandung, Mei 2004, hal 1.

${ }^{2}$ Muchammad Zaidun, "Paradigma Baru Kebijakan Hukum Investasi Indonesia, Suatu Tantangan dan Harapan" Pidato Disampaikan pada Pengukuhan Jabatan Guru Besar dalam Bidang Ilmu Hukum Investasi pada Fakultas Hukum Universitas Airlangga, Surabaya, 12 Juli 2008.

${ }^{3}$ Huala Adolf, Loc.Cit.

4 Larry D. Qiu dan Zhigang Tao, "Export, Foreign Direct Investment, and Local Content Requirement", ditulis untuk Seminar University of Hong Kong, Hong Kong University of Science and Technology, dan Uniiversity of Tokyo, Maret, 2011.
}

pasar yang belum dieksplorasi tersebut, di saat yang sama negara berkembang juga mencoba menjual pasarnya yang potensial melalui penanaman modal asing.

Penanaman modal asing oleh perusahaan multinasional dipandang lebih sesuaibaginegaraberkembangdibandingkan pilihan untuk mengekspor karena memberi keuntungan perluasan lapangan kerja dan meningkatkan transfer teknologi bagi industri domestiknya. Untuk melindungi dan mengembangkan industri domestiknya tersebut, negara berkembang umumnya menekankan local content requirements terhadap penanaman modal asing. ${ }^{5}$

Sebagai suatu kebijakan, local content requirements mensyaratkan perusahaan multinasional untuk menggunakan prosentasetertentudaribahandankomponenkomponen tertentu yang diproduksi dalam negeri sehingga dapat meningkatkan kegiatan industri domestiknya. ${ }^{6}$ Di sisi lain, untuk memelihara kualitas produk akhir yang dihasilkan negara berkembang, perusahaan multinasional perlu untuk melakukan transfer teknologi terhadap industri domestik yang memproduksi komponen lokal. Oleh karena itu, local content requirements merupakan kebijakan populer Pemerintah negara berkembang yang berkaitan dengan penanaman modal asing. ${ }^{7}$

Negara maju menganggap bahwa persyaratan local content requirements merupakan mekanisme inefisiensi ekonomi

${ }^{5}$ Ibid.

${ }^{6}$ Ibid.

7 “TRIMs : What Are TRIMs?", www.intl.econ.cuhk. edu.hk., diakses pada 20 September 2012. 
(economically inefficient) dalam melindungi atau mempromosikan industri domestik negara berkembang. Sebaliknya, negara berkembang menganut sikap preventif. Mereka acapkali menyandarkan diri pada alasan kedaulatan dan menekankan kepada kebutuhan penanaman modal yang dikaitkan dengan aspek pembangunan. ${ }^{8}$ Alasan menerapkan local content tersebut didasarkan pada teori infant industry yang menyatakan bahwa negara berkembang akan mendapatkan banyak keuntungan dari penerapan national economic protection melalui tarif yang tinggi, penerapan kuota impor, dan kebijakan subtitusi impor. Pada kebijakan subtitusi impor, industri di negara berkembang disyaratkan menggunakan komponen dari supplier lokal daripada mengimpor. Proteksi ekonomi ini akan dihapus apabila industri domestik sudah cukup mampu bersaing secara internasional. ${ }^{9}$

Sebagai negara berkembang, Indonesia tentunya harus memperhatikan posisinya dalam perdebatan tentang urgensi penerapan local content. Kebijakan hukum investasi nasional harus mampu menjaga dan melindungi kepentingan nasional (national protection) dalam era kompetitif yang terbuka antar negara berkembang dalam perebutan investasi asing. Menurut Menteri Perindustrian, Mohamad Sulaeman Hidayat, kebijakan tersebut penting untuk mendorong perkembangan industri dan

\footnotetext{
8 Ibid.

9 Gillian Moon, "Capturing the Benefit of Trade? Local Content Requirements in WTO Law and the Human Rights-based Approach to Development", School of Law, UNSW Australia, The Berkeley University Press, www. law.bepress.com., diakses pada 20 September 2012.
}

mengukuhkan Indonesia sebagai penyedia peralatan elektronik Indonesia. Beliau juga menambahkan bahwa setelah kebijakan kandungan lokal berjalan, kualitas perusahaan lokal pendukung industri elektronik ditargetkan meningkat. ${ }^{10}$

Selain itu, Pemerintah juga mengatur tentang local content requirements ini dalam Pasal 18 ayat 3 huruf f Undang-Undang Nomor 25 Tahun 2007 tentang Penanaman Modal. Pengaturan tersebut juga dijabarkan dalam peraturan perundang-undangan yang lebih khusus yakni Peraturan Menteri Perindustrian republik Indonesia Nomor : 16/M-Ind/Per/2/2011 tentang Ketentuan dan Tata Cara Penghitungan Tingkat Komponen DalamNegeri.Halini ditegaskan puladengan adanya Nota Kesepahaman Departemen Perindustrian Republik Indonesia dengan Kementerian Negara Badan Usaha Milik Negara Republik Indonesia Nomor : 522/M-Ind/12/2005 tentang Pengutamaan Penggunaan Produk Dalam Negeri. Adanya regulasi nasional sebagaimana dijabarkan di atas yang mengatur tentang local content requirements merupakan bentuk perlindungan pemerintah akan produk nasional di tengah maraknya produk impor yang membanjiri pasaran Indonesia.

Namun, berdasarkanArticle 2Agreement on TRIMs, maka pengaturan local content requirements tidak diperkenankan karena termasuk dalam illustrative list TRIMs yang melanggar prinsip national treatment dalam GATT 1994. Oleh sebab itu, Indonesia harus melakukan notifikasi mengenai TRIMs yang

10 "Kandungan Lokal Minimal 50 Persen", www. kemenperin.go.id, diakses pada 7 September 2012. 
bertentangan dengan GATT.

Hal esensial yang perlu diperhatikan dalam rangka menarik minat investor untuk menanamkan modal adalah harmonisasi peraturan perundang-undangan dan ketentuan perjanjian internasional. Selain itu, Indonesia berada dalam posisi yang dilematis antara kewajiban memberlakukan prinsip national treatment yang melarang local content dan kebijakan national protection untuk memajukan industri domestiknya.

Adanya problem dilematis dalam harmonisasi peraturan perundang-undangan akan menyebabkan hambatan investasi dan kurangnya kepastian hukum sebagai Negara tujuan investasi. Dengan demikian, arah kebijaksanaan Pemerintah terhadap penyelenggaraan penanaman modal haruslah jelas dan konsisten sehingga dalam pelaksanaannya tidak bias dan tidak mudah berubah sesuai selera pengambil kebijakan. Adanya kebijakan yang terarah diharapkan dapat memberikan peranan signifikan bagi pelaksanaan pembangunan nasional. ${ }^{11}$

Mengingat pentingnya masalah persyaratan local content requirements bagi pemerintah Indonesia, maka permasalahan pokok yang akan diteliti adalah Local content requirements sebagai national protection dan implementasi local content requirements dalam kaitannya dengan prinsip national treatment di Indonesia.

11 Ilman, Aminuddin, "Hukum Penanaman Modal di Indonesia”, Kencana Prenada Media Group, Jakarta, 2010, hal. 47.

\section{Local Content Requirements sebagai Performance Requirements}

Pemerintah host country memiliki berbagai pilihan kebijakan investasi dan perdagangan untuk memaksimalkan keuntungan yang didapat dari pelaksanaan foreign direct investment. Namun, ada beberapa instrumen yang masih sering digunakan oleh negara-negara tersebut yakni performance requirements. ${ }^{12}$

Performance requirements itu sendiri menurut United Nation Conference on Trade and Development didefinisikan sebagai "stimulations, imposed on investors, requiring them to meet certain specified goals with respect to their operations in the host country." Adanya persyaratan yang dibebankan kepada investor untuk memenuhi kriteria tertentu dalam kaitannya dengan kegiatan operasional mereka merupakan unsur esensial dalam penerapan performance requirements.

Pada prinsipnya, performance requirments dapat dibagi dalam 3 (tiga) jenis (tabel 1). Pertama, jenis performance requirements yang secara eksplisit dilarang oleh WTO melalui Agreement on TradeRelated Investment Measures (TRIMs) karena bertentangan denganArticle III danXI GATT1994. Kedua, persyaratan-persyaratan yang secara eksplisit dilarang atau dibatasi oleh perjanjian-perjanjian interegional, regional maupun bilateral. Sedangkan kategori ketiga meliputi persyaratan-

${ }^{12}$ United Nations Conference on Trade and Development, "ForeignDirectInvestmentandPerformamce Requirements : New Evidence From Selected Countries", United Nation, New York and Geneva, 2003, hal 2. 
persyaratan yang bukan merupakan subjek yang diawasi melalui berbagai perjanjian investasi internasional. ${ }^{13}$

Menurut Sanwani Nasution dan Mahmul Siregar, setidaknya ada 3 bentuk persyaratan yang dapat ditemukan dalam penerapan local content requirements oleh negara penerima modal yang memuat aspekaspek sebagai berikut ${ }^{14}$ :

a. pembelian atau penggunaan barangbarang buatan dalam negeri

b. jumlah kandungan lokal yang dipergunakan dalam proses produksi ditentukan secara pasti

c. merupakan syarat yang harus dipenuhi untuk dapat melakukan kegiatan investasi asing

Ketiga bentuk persyaratan tersebut tentunya dapat menimbulkan berbagai akibat seperti adanya diskriminasi terhadap barang impor, pemaksaan terselubung untuk membeli produkdalamnegeri, pemilik modal kehilangan kesempatan untuk menentukan pilihan kebijakan dalam menjalankan usaha, dan pelaku usaha domestik yang tidak kompetitif untuk jangka panjang. ${ }^{15}$

Adanya diskriminasi terhadap barang impor dapat terjadi karena produk dalam negeri lebih diutamanakan dan dianjurkan untuk digunakan dibandingkan produk impor. Selain itu penerapan local content yang biasanya dituangkan dalam produk perundang-udangan yang apabila tidak diikuti dengan prinsip transparansi akan

13 Ibid, hal 3.

${ }^{14}$ Sanwani Nasution dan Mahmul Siregar, "Perdagangan Internasional dan Investasi", Program Studi Ilmu Hukum, USU, Medan, 2009.

15 Ibid. memicu pemaksaan terselubung untuk membeli produk dalam negeri. Akibatnya investor sebagai pemilik modal akan kehilangan kesempatan menentukan pilihan untuk memilih produk yang dinilai lebih efisien dan tentunya berakibat pada produksinya. Dari sisi pelaku usaha domestik, apabila Pemerintah tidak tanggap dalam mendorong unsur kompetitif maka para pelaku usaha domestik tersebut tidak akan menunjukkan peningkatan persaingan secara sehat dan lebih cenderung bergantung pada program Pemerintah melalui kebijakan local content.

Local content requirements merupakan suatu kebijakan yang dilarang karena tindakan tersebut merupakan bentuk perlakuan diksriminatif terhadap barang impor. Dengan adanya kewajiban bagi investor untuk membeli atau menggunakan barang-barang buatan dalam negeri, maka dalam hal ini Pemerintah telah memberikan perlakuan yang lebih baik pada barang buatan dalam negeri. Melalui persyaratan kandungan lokal sebenarnya Pemerintah host country telah membatasi akses pasarnya bagi barang-barang yang sama dari negaranegara anggota lain.

Pengaturan local content requirements tidak secara tegas dinyatakan dalam Undang-Undang Nomor 25 Tahun 2007 tentang Penanaman Modal. Secara implisit investasi Indonesia memberikan perlakuan khusus kepada investor maupun perusahaan multinasional yang menggunakan produk dalam negeri melalui fasilitas-fasilitas yang disediakan Pemerintah. Pengaturan tersebut dinyatakan dalam Pasal 18 (3) huruf f 
Undang-Undang Nomor 25 Tahun 2007 tentang Penanaman Modal (selanjutnya disebut UUPM) sebagai berikut :

\section{"Penanaman modal yang mendapat} fasilitas sebagaimana dimaksud pada ayat (2) adalah yang sekurang-kurangnya memenuhi salah satu kriteria berikut ini : (f) industri yang menggunakan barang modal atau mesin atau peralatan yang diproduksi dalam negeri."

Adapun bentuk fasilitas yang dimaksud dalam ketentuan di atas dapat berupa pengurangan pajak penghasilan dari penghasilan netto sampai tingkat tertentu, pembebasan atau keringanan bea masuk atas impor barahan baku, barang modal, mesin atau impor peralatan untuk keperluan produksi yang belum dapat diproduksi dalam negeri, pembebasan atau penangguhan pajak pertambahan nilai atas impor barang modal atau mesin, serta keringanan pajak bumi dan bangunan. ${ }^{16}$

Namun fasilitas-fasilitas ini diberikan berdasarkan kebijakan industri nasional yang ditetapkan Pemerintah dan juga harus memperhatikan syarat dan ketentuan lebih lanjut sebagaimana yang terdapat dalam Pasal 18 ayat (5) dan (6), seperti pembebasan atau pengurangan pajak penghasilan hanya diberikan kepada investor baru yang merupakan industri pionir. Selain itu fasilitas tersebut hanya akan berlaku bagi penanaman modal asing yang berbentuk perseroan terbatas. ${ }^{17}$

\footnotetext{
${ }^{16}$ Pasal 18 (4) UU No. 25 Tahun 2007 tentang Penanaman Modal.

${ }_{17}$ Pasal 20 UU No. 25 Tahun 2007 tentang Penanaman Modal.
}

\section{Prinsip National Treatment}

Padadasarnyaprinsipnationaltreatment merupakan prinsip yang mendasari setiap perjanjian-perjanjian internasional untuk menghindari diskriminasi yang berbasis nationality. ${ }^{18} \mathrm{Di}$ dalam human rights treaties $^{19}$ pun terdapat dasar-dasar national treatment yang dinyatakan sebagai "equal treatment to all similarly situated person within their jurisdictions."

Dasar-dasar untuk menghindari diskriminasi tersebut tentunya melekat pada perjanjian-perjanjian di bidang investasi dimana fungsinya adalah untuk menetralisir adanya potensi negara untuk melakukan proteksi terhadap investor-investor dan produsen domestiknya dalam menghadapi persaingan asing. ${ }^{20}$

Menurut WTO, prinsip national treatment merupakan suatu prinsip yang menyaratkan kepada host countries untuk memperlakukan investasi asing maupun investor-investor asing dengan perlakuan yang sama dengan yang diterapkan kepada investor-investor nasional. ${ }^{21}$ Penerapan

${ }^{18}$ Andrea K. Bjorklund, "National Treatment", Oxford University Press, 2008, hal 2.

${ }^{19}$ Article I European Convention for the Protection of Huma Rights and Fundamental Freedoms (1950) stated "The High Contracting Parties shall secure to everyone within their jurisdiction the rights and freedoms defined in Section I of this Convention" Article 2 Universal Declaration of Human Rights (1948) stated "Everyone is entitled to all the rights and freedoms set forth in this Declaration, without distinction of any kind, such as race, colour, sex, language, religion, political or other opinion, national or social origin, property, birth or other status. Furthermore, no distinction shall be made on the basis of the political, jurisdictional or international status of the country or territory to which a person belongs, whether it be independent, trust, non-self-governing or under any other limitation of sovereignty."

${ }^{20}$ Andrea K. Bjorklund, Loc. Cit.

21 "An Informal Guide to WTO Speak", www.wto. org., diakses pada 15 November 2012. 
prinsip national treatment sendiri bersumber pada Article III GATT 1994 yang mewajiban kepada negara anggota untuk menerapkan prinsip national treatment terhadap baik terhadap peraturan-peraturan nasional di negaraanggota, dalampajakinternal, maupun dalam perdagangan barang. ${ }^{22}$ Kewajiban tersebut dinyatakan dalam Article III (1) GATT 1994 secara jelas dinyatakan bahwa tujuan WTO mengatur prinsip national treatment adalah untuk menghindari adanya campur tangan pemerintah negara anggota dalam menghadapi persaingan produkproduk nasional dengan produk-produk asing.

Dari ketentuan di atas, dapat ditarik 3 (tiga) elemen penting yang harus dipenuhi agar suatu negara dapat dinyatakan melanggar prinsip national treatment, yaitu (1) bahwa produk-produk impor dan produk-produk lokal yang disengketakan merupakan "like product"23, (2) bahwa tindakan yang diambil Pemerintah berdasarkan hukum, peraturan-peraturan, atau persyaratan nasional yang berpengaruh terhadap penjualan secara internal, penawaran untuk menjual, transportasi, distribusi, atau penggunaannya, dan elemen yang terakhir (3) bahwa imported product tidak mengalami perlakuan yang sama

22 Jurgen Kurtz, "The Use and Abuse of WTO Law in Investor-State Arbitration : Competition and Its Discontents", The European Journal of International Law Vo;1. 20 No. 3, 2009.

${ }^{23}$ Article2.6 Anti-Dumping Agreement; Article 15.1 fn.46 Agreement on Subsidies and Countervailing Measures define like products as a product which is identical, i.e. alike in all respects to the product under comsideration, or in the absence of such product, another product which, although not alike in all respects, has characteristics closely resembling those of the product under consideration. dengan yang produk-produk domestik. ${ }^{24}$

Indonesia telah menerapkan prinsip National Treatment dalam ketentuan undang-undangnya yakni Undang-Undang Nomor 25 Tahun 2007 tentang Penanaman Modal (untuk selanjutnya disebut UUPM). Hal ini berarti Pemerintah memberikan jaminan perlakuan yang sama kepada semua investor yang melakukan aktivitas penanaman modal di Indonesia. Jaminan tersebut diatur dalam Pasal 4 ayat (2) UU PM yang berbunyi sebagai berikut :

"Dalam menetapkan kebijakan dasar sebagaimana dimaksud pada ayat (1), Pemerintah : (a) memberi perlakuan yang sama bagi penanam modal dalam negeri dan penanam modal asing dengan tetap memperhatikan kepentingan nasional."

Lebih lanjut, Pemerintah memberikan definisiprinsipNationalTreatmentinisebagai perlakuan yang sama dimana Pemerintah tidak membedakan perlakuan terhadap penanam modal yang telah menanamkan modalnya di Indonesia, kecuali ditentukan lain oleh peraturan perundang-undangan. ${ }^{25}$ Jelas terlihat dari ketentuan Pasal 4 ayat (2) UUPM bahwa Indonesia lebih condong ke arah post-entry national treatment dengan memberikan pengecualian melalui regulasi nasionalnya.

Dengan demikian Indonesia berhak memberikan definisi atau batasan terhadap ketentuan prinsip national treatment dalam UUPM. Pengecualian terhadap prinsip

24 The Appelate Body of WTO explained the three elements of violation of Article III : 4 GATT 1994 in Koreavarious Measures on Beef Case.

25 Penjelasan pasal 4 ayat (2) huruf a UU No. 25 Tahun 2007 tentang Penanaman Modal. 
tersebut tertuang dalam Pasal 12 UUPM yang memuat bidang-bidang usaha terbuka bagi penanaman modal dan bidang usaha yang dinyatakan tertutup dan terbuka dengan persyaratan. Bidang-bidang usaha yang berkaitan dengan keamanan negara seperti produksi senjata, mesiu, alat peledak, dan peralatan perang merupakan contoh bidang usaha yang bersifat tertutup.

Secara keseluruhan dapat dipahami bahwa UUPM tidak memberikan perlakuan yang benar-benar sama antara PMA dan PMDN. Beberapa ketentuan dari UUPM tersebutmembebankansejumlahpembatasan penanaman modal terhadap PMA seperti adanya pembatasan bidang usaha tertutup dan bidang usaha terbuka bagi investasi sebagaimana di jelaskan di atas. ${ }^{26}$

Pasal mengenai pembatasan bidang usaha tersebut dapat memicu protes dari investor asing yang akan menanamkan modalnya di Indonesia. Namun ketentuan tersebut tidak dilarang dalam kesepakatan internasional di bidang perdagangan karena tujuan dari TRIMS bukanlah untuk untuk mengatur pembatasan bidang usaha. TRIMS hanya mengatur pendisiplinan performance requirements ${ }^{27}$ yang berdampak negatif pada kelancaran perdagangan barang. ${ }^{28}$

\section{Prinsip National Treatment dan ImplementasiLocalContent Requirements di Indonesia}

\footnotetext{
26 Mahmul Siregar, Op.Cit, hal 10.

27 Menurut United Nation Conference on Trade and Development, performance reqquirements didefinisikan sebagai "stimulations, imposed on investors, requiring them to meet certain specified goals with respect to their operations in the host country."

28 Ibid.
}

Pada dasarnya, implementasi local content requirements di berbagai negara umumnya diwujudkan dalam 3 (tiga) bentuk, sebagai berikut ${ }^{29}$ :

a. pembelian atau penggunaan barangbarang buatan dalam negeri.

b. jumlah kandungan lokal yang dipergunakan dalam proses produksi ditentukan secara pasti

c. merupakan syarat yang harus dipenuhi untuk dapat melakukan kegiatan investasi asing.

Indonesia menerapkan bentuk implementasi local content dalam pembelian atau penggunaan barang-barang buatan dalam negeri seperti elektronik maupun otomotif. Selain itu juga terdapat regulasi melalui Peraturan Menteri Perdagangan Republik Indonesia Nomor : 16/M-Ind/ Per/2/2011 tentang Ketentuan dan Tata Cara Penghitungan Tingkat Komponen Dalam Negeri maupun optimalisasi Pemerintah untuk menggerakkan pertumbuhan dan memberdayakan industri dalam negeri melalui peningkatan produk dalam negeri yang dituangkan dalam Inpres No. 2 Tahun 2009 tentang Penggunaan Produk Dalam Negeri Dalam Pengadaan Barang/ Jasa Pemerintah. Namun, untuk bentuk implementasi ketiga di dalam UUPM tidak secara tegas disebutkan bahwa penerapan kandungan lokal harus dipenuhi.

Sornarajah menyatakan bahwa pelanggaran national treatment terjadi ketika performance requirements hanya diterapkan kepada investor asing saja,

${ }^{29}$ Sanwani Nasution dan Mahmul Siregar, Op.Cit., slide 14. 
sebagaimana dikutip berikut ini :

"national treatment will certainty be violated if performance requirements are imposed only on foreign investors". ${ }^{30}$

Menurutnya implementasi local content requirements merupakan salah satu bentuk performance requirements yang dilarang dalam GATT. Apabila diterapkan kepada investor asing dengan tujuan untuk mendapatkan keuntungan sebesar-besarnya bagi negara penerima modal tetapi tidak dibebankan kepada industri domestiknya maka termasuk melanggar prinsip national treatment.

Selain itu sebagai negara berkembang, Indonesia memiliki opsi untuk mengecualikan penerapan bidang-bidang yang dikenai kewajiban local content asal diterapkan secara transparan dalam regulasi penanaman modal seperti UUPM. Opsi tersebut merupakan bentuk prinsip transparansi yang dianjurkan oleh WTO karena WTO memberikan keleluasaan negara untuk membatasi definisi national treatment asal dipublikasikan secara terbuka dan transparan melalui undang-undang. ${ }^{31}$

Akan tetapi untuk penerapan local content requirements tidak termasuk dalam pengecualian prinsip national treatment dalam UUPM. Dengan tidak dimasukkannya local content requirements ke dalam UUPM maka Indonesia akan dianggap melanggar prinsip national treatment GATT 1994 dimana local content dipandang sebagai performance requirements yang merupakan hambatan perdagangan di bidang regulasi.

\footnotetext{
${ }^{30}$ M. Sornarajah, Op. Cit., hal 326.

31 Mari Pangestu, Op. Cit., hal 10.
}

\section{Alternatif Solusi Inkonsistensi Penerapan Local Content Requirements di Indonesia}

Pada dasarnya hampir semua perjanjian internasional tentang investasi ataupun perjanjian perdagangan bebas dalam kerangka regional memuat tentang country specific exception. Pengecualian tersebut ditujukan bagi implementasi prinsip Most Favoured Nation (MFN) atau National Treatment yang dirasa perlu untuk mendukung tujuan pembentukan perjanjian investasi itu sendiri. Alasan lain yang mendukung adalah karena keadaan suatu negara yang membutuhkan perlakuan khusus berkaitan dengan kondisi ekonomi dan kesiapan industri domestiknya dalam menghadapi persaingan global yang menuntut persaingan bebas dan dihapusnya hambatan-hambatan investasi.

Terdapat 3 hal yang mendasari perkecualian ini, yakni :

1. Negara sebagai pihak dalam perjanjian memiliki hak untuk memberikan perlakuan berbeda antara investor asing dan investor domestik

2. Adanya perlakuan yang berbeda tersebut dituangkan dalam hukum dan peraturan-peraturan terkait di Negara tersebut.

3. Alasan pemberlakuan country specific exception khususnyaterhadapindustriindustri atau aktifitas-aktifitas tertentu dan spesifik adalah karena kondisi perekonomian nasional dan kebijakan sosial. 
Sebagai negara yang sedang giat mengembangkan investasi, unsur-unsur dari country specific exception di atas kiranya dapat diadopsi Indonesia dalam perarturan perundang-undangannya. Pemerintah memiliki hak untuk memberikan perlakuan berbeda terhadap investor asing sebagai bentuk pengecualian dari prinsip national treatment. Pengecualian ini juga diperbolehkan dalam Pasal 3 TRIMs yang menyatakan bahwa :

"All exceptions under GATT 1994 shall apply, as appropriate, to the provisions of this Agreement."

Selain itu, implementasi local content requirements berkaitan dengan alasan kondisi perekonomian nasional Indonesia yang harus bertahan di tengah serbuan produk-produk asing. Adanya persaingan ini membuat Pemerintah merasa harus melindungi industri domestik dan produkproduk domestik dengan menerapkan persyaratan local content. Alasan tersebut sudah memenuhi unsur ketiga dalam country specific exception.

Di sisi lain, untuk menerapan secara penuh pengecualian country specific maka Pemerintah harus memenuhi unsur yang kedua yakni menuangkan bentuk perlakuan yangberbedamelaluipenerapanlocalcontent ke dalam peraturan perundang-undangan nasional. Dalam hal ini Pemerintah dapat mengadopsi cara yang dilakukan Meksiko dengan mengatur pengecualian prinsip national treatment yang diwajibkan TRIMs dan GATT 1994 dalam UUPM.

Sebagaimana diketahui bahwa UUPM hanya mengatur pengecualian prinsip non diskriminasi dengan memisahkan bidangbidang usaha yang tertutup dan terbuka, maupun bidang usaha yang terbuka dengan persyaratan. Sangat penting untuk menambahkan bidang-bidang usaha yang diwajibkan memenuhi penerapan local content atau Tingkat Kandungan Dalam Negeri (TKDN) dalam UUPM sebagai bentuk transparansi dan menghindari inkonsistensi Indonesia sebagai negara tujuan investasi dan negara yang telah meratifikasi TRIMs dan GATT.

Adanya inkonsistensi antara prinsip national treatment yang tercantum dalam UUPM dengan implementasi local content requirements dalam peraturan pelaksana merupakan hal yang harus dihindari karena dapat menimbulkan distorsi perdagangan. Lebih jauh lagi dalam kaitannya dengan investor, mereka menginginkan adanya kepastian hukum yang tercermin dari harmonisasi peraturan perundang-undangan Indonesia. "country specific exception should refer to the relevant law and other legal authority which would define the scope of exception." Dengan demikian country specific exception merupakan instrument yang sesuai bagi kondisi perekonomian Indonesia saat ini.

\section{Pentingnya Prinsip Transparansi dalam Implementasi Local Content Requirements}

Kesadaran tiap negara anggota untuk mendukung keterbukaan sangat diperlukan dalam mencapai keberhasilan TRIMs. Keterbukaan informasi mengenai 
hambatan-hambatan penanaman modal merupakan salah satu faktor yang dapat menarik minat investor untuk menanamkan modalnya, karena keterbukaan informasi akan membantu investor dalam pengambilan keputusan bisnisnya. ${ }^{32}$

Dengan transparansi, maka hukum dapat digunakan sebagai media prediksi dan hal ini akan menunjang pembangunan ekonomi karena kepercayaan investor akan meningkatkan arus modal yang menguntungkan bagi negara host country. Oleh karena itu Article 6 (2) TRIMs mewajibkan negara-negara anggota GATT untuk memberitahukan kepada Sekretariat WTO publikasi-publikasi yang memuat ketentuan TRIMs termasuk publikasi mengenai ketentuan local content apa saja yang diterapkan Pemerintah.

Keterbukaan informasi mengenai TRIMs juga harus diberikan kepada setiapanggota yang meminta layanan informasi serta layanan konsultasi bilateral. ${ }^{33}$ Namun keterbukaan informasi tidak mengharuskan negara anggota memberikan informasi-informasi yang dapatmenghalangi penegakan hukum, bertentangan dengan kepentingan umum, dan informasi yang dapat merugikan kepentingan perusahaan perdagangan tertentu.

Kebijakan local content hendaknya diarahkan untuk menciptakan rasa kompetitif bagi industri-industri domestik. Dalam hal ini Pemerintah harus berhatihati karena jika tidak akan menimbulkan proteksi terselubung bagi investasi dan akan

\footnotetext{
32 Ibid, hal 39.

33 Article 6 (3) TRIMs.
}

berdampak buruk terhadap perekonomian Indonesia ke depan.

\section{Kesimpulan}

Kebijakan local content requirements di Indonesia dituangkan dalam Program Peningkatan Penggunaan Produk Dalam Negeri (P3DN) dengan tujuan untuk memberdayakan produk nasional dengan prosentase kandungan lokal tertentu demi melindungi industri domestik dari serbuan produk impor (national protection). Kebijakan ini diterapkan Pemerintah melalui regulasi nasionalnya, salah satunya adalah Peraturan Menteri Perindustrian Republik Indonesia No. 16/M-Ind/ Per/2/2011 tentang Ketentuan dan Tata Cara Penghitungan Tingkat Komponen Dalam Negeri. Jaminan untuk melindungi kepentingan nasional masing-masing negara merupakan kebebasan setiap negara yang terwujud dalam prinsip kedaulatan negara, namun kedaulatan tersebut tidak mutlak. Negara hanya diberikan kedaulatan untuk menentukan kebijakan penanaman modalnya sepanjang tidak menimbulkan hambatan perdagangan.

Setiap negara yang menghendaki masuknya penanaman modal asing harus mematuhi prinsip national treatment yang mensyaratkan kepada host country untuk memberi perlakuan sama antara investor/ investasi asing dan investor/investasi lokal. Adanyapenerapanlocalcontentrequirements di Indonesia merupakan pelanggaran terhadap prinsip national treatment yang diatur dalam Article III:4 GATT 1994 dan Annex 1A TRIMs. Beberapa opsi yang 
dapat ditawarkan sebagai alternatif solusi inkonsistensi Indonesia sebagai pihak yang telah meratifikasi WTO dan TRIMs adalah dengan (a.) country specific exception yang diberikan dengan cara mengecualikan atau membatasi partisipasi investor asing pada bidang-bidang usaha industri tertentu atas dasar perekonomian nasional dan kebijakan sosial; (b.) mekanisme notifikasi yang memegang peranan penting terkait investasi karena pembatasan yang telah dinotifikasikkan dapat terus dilanjutkan dan terbebas dari tuntutan hukum yang diajukan oleh negara lain atas pelanggaran TRIMs; (c.) prinsip transparansi yang terwujud dalam sikap negara anggota untuk mendukung keterbukaan dalam mencapai keberhasilan TRIMs. Selain untuk mendukung komitmen suatu negara, penerapan prinsip transparansi juga sebagai faktor yang dapat menarik investor untuk menanamkan modalnya.

\section{Daftar Bacaan}

Adolf, Huala, "Perjanjian Penanaman Modal dalam hukum Perdagangan Internasional (WTO)", Bandung, Mei 2004.

\section{"Hukum Perdagangan} Internasional", PT Raja Grafindo Persada, Rajawali Pers, Jakarta, 2009.

Arifin, Sjamsul, "Masyarakat Ekonomi ASEAN 2015 : Memperkuat SinergiASEAN di Tengah Kompetisi Global”, PT. Elex Media Komputindo, Kompas Gramedia-Jakarta.

Hadjon, Philipus M., "Pengkajian Ilmu Hukum, Makalah Metode Penelitian Hukum Normatif”, Pusal Penelitian dan Pengembangan Hukum, Lembaga Penelitian Universitas Airlangga, bekerja sama dengan Fakultas Hukum Universitas Airlangga, 11-12 Juni 1997.

Hatta, "Perdagangan Internasional Dalam Sistem GATT dan WTO; AspekAsspek Hukum dan Non Hukum", Refika Aditama, September 2006

Ilmar, Aminuddin, "Hukum Penanaman Modal di Indonesia", Kencana Persada Media Group, Jakartta, 2010.

Moon, Gillian "Capturing the Benefit of Trade? Local Content Requirements in WTO Law and the Human Rightsbased Approach to Development", School of Law, UNSW Australia, The Berkeley University Press, www. law.bepress.com., diakses pada 20 September 2012.

Pangestu, Mari, "Perjanjian Internasional Mengenai Investasi : GATT 1994/ WTO dan APEC", Bahan Ajar Hukum Investasi.

Marzuki, Peter Mahmud, "Penelitian Hukum", Kencana Prenada Media Group, Jakarta, 2011.

Sarwani Nasution dan Mahmul Siregar, "Perdagangan Internasional dan Investasi", Program Studi Ilmu Hukum, USU, Medan, 2009.

Siregar, Mahmul, “Kesepakatan Perdagangan yang Terkait dengan Persyaratan Penanaman Modal", Universitas Sumatera Utara Repository, 2005.

Sengketa Perdagangann Internasional dan Penanaman Modal', Dosen Fakultas Hukum dan Program Studi Ilmu Sekolah Pascasarjana Universitas 
Sumatera Utara.

Sornarajah, M., "The Internatioal Law on Foreign Investment", Cambridge University Press, 1995.

Zaidun, Muchammad, "Paradigma Baru Kebijakan Hukum Investasi Indonesia, Suatu Tantangan dan Harapan" Pidato Disampaikan pada Pengukuhan Jabatan Guru Besar dalam Bidang Ilmu Hukum Investasi pada Fakultas Hukum Universitas Airlangga, Surabaya, 12 Juli 2008.

Zaidun, Muchammad, "Penerapan PrinsipPrinsip Hukum Internasional PenanamanModalAsingdiIndonesia", Disertasi untuk memperoleh Gelar Doktor Dalam Ilmu Hukum Program Pascasarjana Universitas Airlangga, Surabaya, 2005.

\section{Perundang-Undangan :}

General Tariffs and Trade (GATT)

Agreement on Trade-Related Investment (TRIMs)

The ASEAN Comperehensive Investment Agreement (ACIA)

\section{ASEAN Free Trade Area (AFTA)}

Undang-Undang Nomor 25 Tahun 2007 tentang Penanaman Modal

Peraturan Menteri Perindustrian Republik Indonesia No. 16/M-Ind/ Per/2/2011 tentang Ketentuan dan Tata Cara Penghitungan Tingkat Komponen Dalam Negeri

Nota Kesepahaman Departemen Perindustrian Republik Indonesia dengan Kementerian Negara Badan Usaha Milik
Negara Republik Indonesia tentang Pengutamaan Produk Dalam Negeri

\section{Jurnal/Artikel :}

www.wto.org

Anwar, Syaiful, "Mengenal World Trade Organization (WTO)", Widyaiswara Pusdiklat Bea dan Cukai, www.bppk. depkeu.go.id.

"Asosiation of South East Asian Nations (ASEAN)", www.ditjenkpi.kemendag. go.id.

ASEAN Investment Area (AIA) Council", www.aseansec.org.

"ASEAN Free Trade Area (AFTA)", Badan Kebijakan Fiskal Pusat Pendapatan Negara, Tim Tarif Departemen Keuangan Republik Indonesia, www. tarif.depkeu.go.id.

"ASEAN Compeherehnsive Investment Agreement (ACIA) Enters Into Force Creating a Stable and Predictable Business Investment Environment," Philipine Information Agency, www. pia.gov.ph.

Benu, Nur Juanita, "Properti Tumbuh, 175 Produk Industri Bakal Ketularan", www.property.okezone.com.

Budhiartha, I Nyoman Putu, "Urgensi Ratifikasi GATT/WTO Melalui Undang-Undang Nomor 7 Tahun 1994 Dalam Menentukan Kebijaksanaan Investasi dan Perdagangan Indonesia”, www.jurnal.pdii.lipi. go.id.

Canada Administration on The Foreign Investment Review Act, FIRA Panel Report, Document 30 BISD 157 (1984). 
"Dimulainya Verfikasi TKDN Tahun 2012”, Webside P3DN Kementerian Perindustrian, www.tkdn.kemenperin. go.id.

Ferraro, Vincent, "Dependency Theory: An Introduction, in the Development Economics Reader", London, Routledge, 2008, www.mtholyoke. edu/acad/intrel/depend.htm.

Financial Times Lexicon, Emily Bussiness School, www.lexicon.ft.com.

"Jero : Capaian TKDN SK Migas 61\%", www.id.berita.yahoo.com.

"Kandungan Lokal Minimal 50 Persen", www.kemenperin.go.id.

Kurtz, Jurgen, "The Use and Abuse of WTO Law in Investor-State Arbitration : Competition and Its Discontents", The European Journal of International Law, Vol. 20, No. 3, 2009.

Maret, Dwi, "Prinsip National Treatment Dalam Penanaman Modal Asing di Indonesia, Antara Liberalisasi dan PerlindunganKepentinganNasional", www.dwimaret.blogspot.com.

Meliana Lumbatoruan dkk, "Transfer Teknologi PMA di IndonesiaStudi Kasus: PT Freeport Indonesia", www. melianalumbatoruan.wordpress.com.
Peter Muchlinski dkk, "The Oxford Handbook of International Investment Law”, Oxford University Press (edited), www.google.books.co.id.

"Program P3DN Membentengi Produk Dalam Negeri", Fakultas Ekonomi dan Bisnis Universitas Padjajaran, www.fe.unpad.ac.id.

Radjagukguk, Erman, "TRIMs and Investasi", www.ermanhukum.com.

"The Local Content Paradox at the WTO : A Minor Lapse or Lapse or Organised Hypocrisy?", International Centre for Trade and Sustainable Development, Volume 12, Number 3, Mei 2008, www.ictsd.org.

"TRIMs and Local Content", International Centre for Trade and Sustainable Development, Volume 12, Number 3, May 2008, www.ictsd.org.

"Technical Information on Trade and Investment, Distinction Between Paragraph 1 and 2 of The Illustrative List", www.wto.org.

United Nations Conference on Trade and Development, "National Treatment", United Nation New York and Geneva, 1999, www.unctad.org. 